\title{
CLASSICAL AND NEW ASPECTS IN DEGRADATION OF AROMATIC XENOBIOTICS
}

\author{
Evgenia K. Vasileva, Tsvetomila I. Parvanova-Mancheva, Venko N. Beschkov
}

\begin{abstract}
Organic chemical mixtures are prevalent in waste waters from industrial and municipal sources as well as in contaminated groundwater. Phenols are pollutants found in wastewaters from oil refineries, chemical plants, explosives, resins and coke manufacture, coal conversion, pesticide and textile industries. The main contaminants of refinery wastewater include phenols, polycyclic aromatic hydrocarbons (PAHs) as well as heavy metals. Among these toxic pollutants, phenols are considered to be the most hazardous ones, and they are certainly the most difficult to remove. Phenolic compounds are toxic at relatively low concentration. Because of these low concentrations the most suitable methods for their removal are the microbial ones. The present work is a review of biodegradation of phenol. Degradation of phenol occurs as a result of the activity of a large number of microorganisms including bacteria, fungi and actinomycetes. There are reports on ma33ny microorganisms capable of degrading phenol through the action of variety of enzymes. These enzymes may include oxygenases, hydroxylases, peroxidases, tyrosinases, oxidases etc. Batch experiments were carried out in a different bioreactors. Biodegradation of organic chemicals by microbes using pure cultures can produce toxic intermediates. This problem may be overcome by the use of mixed cultures that have a wider spectrum of metabolite degradation properties.

In this revew we described also some new technology for biodegradation of phenol like: different immobilization, FISH (Fluorescence in-situ hybridization) analysis, nanobiotechnologies and etc.
\end{abstract}

Key words: phenol, biodegradation, microorganisms, enzymes, immobilization, FISH analysis, nanobiotechnologies

\section{INTRODUCTION}

Phenol is one of the main pollutants in industrial waste water. Phenol and its vapors are erosive to the respiratory tract, the skin and the eyes. With the development of industrial production and continuous demand for chemicals, a large volume of wastewater containing phenols was discharged into the aquatic environment. Moreover, chemical leakage further increased the emission of phenols into aquatic systems. Phenol and its methylated derivative (cresols) were selected due to their extensive use in industry and ecotoxicity to freshwater and marine organisms. The review from Duana et al. (2018) [1] focused on the ecotoxicity of phenol and m-, o-, and p-cresol on aquatic systems. The mechanism of action of phenols was also discussed. The aim of literature review [1] was to summarise the knowledge of the behaviour, and toxicity on marine and freshwater organisms, of phenols as well as to try to select a series of sensitive biomarkers suitable for ecotoxicological assessment and environmental monitoring in aquatic environments.

Phenols are typically classified into two main types on the basis of the number of phenol units, including polyphenols and simple phenols. Phenols are not only synthesized industrially, but also produced by plants and microorganisms [2,3]. They could accumulate in surface water, ground water and soil when released into the environment [4]. Generally, microorganisms can be applied to water treatment with phenol pollution, such as Pseudomonas sp. and Acinetobacter sp. [5].

Accidental spills of phenol, which happened in the Port of Gothenburg (Sweden) [6] and Xin'an River (China), caused leakage of a significant amounts of phenol, posing a threat to water quality and aquatic systems (China Chemical Safety Association (2011) [7]; HELCOM (2002) [8]). Due to their high water-solubility (phenol, $8.28 \mathrm{~g} / 100$ $\mathrm{mL}$; cresols, 2.15-2.60 g/100 mL), phenol and cresols can persist at a high concentration in aquatic environments [9].

\section{BIODEGRADATION STUDIES}

\section{MECHANISM OF AEROBIC PHENOL DEGRADATION}

It was investigated detoxification potential and rehabilitation of activated sludge (AS) after shock loading of Sofia's wastewater treatment plant 'Kubratovo' with mazut [10]. The studied enzymological indicators for the detoxification of the aryl-containing contaminants in mazut are the key enzymes of the preparatory pathways of the cleavage of the benzene ring. Parallel to this authors studied the succinate dehydrogenase activity, which is an indicator of the functioning of the cycle of tricarboxylic acids (CTC) on the one hand, and the infusion of the metabolic products of detoxification in the central metabolic pathways, on the other (Fig. 1). 


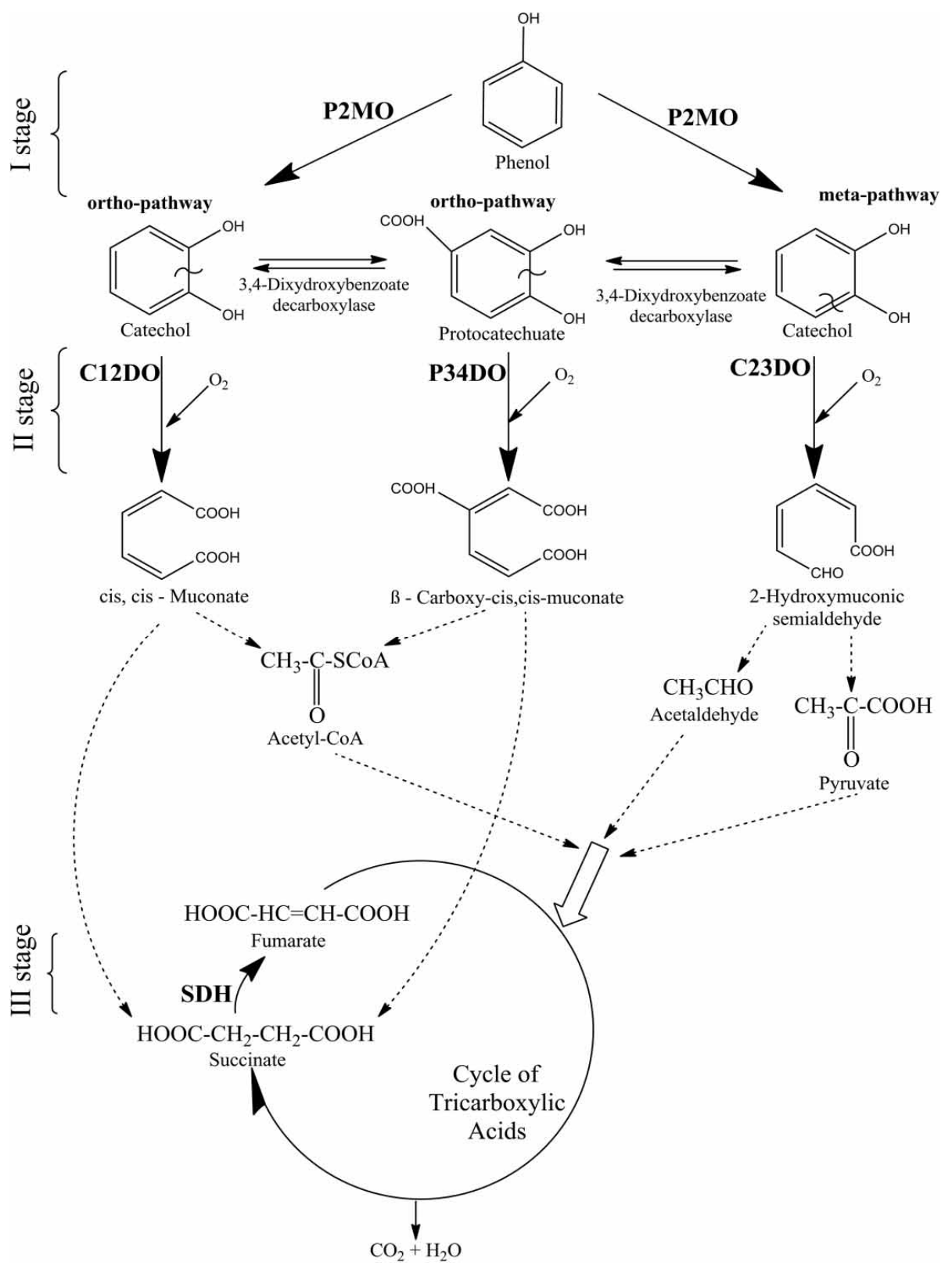

Fig. 1. Phenol biodegradation pathways and key enzymes in different stages [11]

The results show that despite the elapsed period of 16 days, activated sludge (AS) is still in a phase of damage due to the experienced intoxication shock. The detoxification potential, indicated by the activity of the oxygenases and succinate dehydrogenase (SDH), in this first phase of adaptation shows a reduction of the oxygenase activity as phenol 2-monooxygenase (P2MO), catechol 1,2-dioxygenase (C12DO), protocatechuate 3,4-dioxygenase (P34DO), catechol 2,3-dioxygenase (C23DO) and total dioxygenase TDO. In first adaptation phase the meta-mechanism for cleavage of the benzene ring is slightly activated, which pathway is shorter, more effective for detoxification, while the enzymes are driven by coordinated synthesis or are predominantly constitutive. The cleavage is catalyzed by specific metalloenzymes dioxygenases, divided into intradiol dioxygenases which cleave the ring on ortho-position to the hydroxyl substituent and extradiol dioxygenases which cleave on meta-position [12,13] Orthopathway is the oxidation of catechol to cis, cismuconate in a reaction catalyzed by $\mathrm{C} 12 \mathrm{DO}$, and meta-pathway is the oxidation of catechol to 2- 
hydroxymuconic semialdehyde catalyzed by C23DO. The cleavage of the benzene ring of protocatechuate is carried out by $\mathrm{P} 34 \mathrm{DO}$, with the product $\beta$-carboxy-cis, cis-muconate $[14,11]$. These processes can be realized at the conditions of denitrification at low oxygen concentration. In the denitrification zone, the rate of detoxification processes are lower. The enzyme mechanisms of this low rate detoxification potential present applied and scientific interest.

\section{MECHANISM OF ANAEROBIC PHENOL DEGRADATION}

The efficiency of biodegradation of arylcontaining xenobiotics is influenced by the type of the organic pollutant, the nature of the organism, the enzyme involved, the mechanism of degradation and the nature of the influencing factors.

An anaerobic phenol metabolism [15] in a denitrifying Pseudomonas sp. is shown in Fig. 2

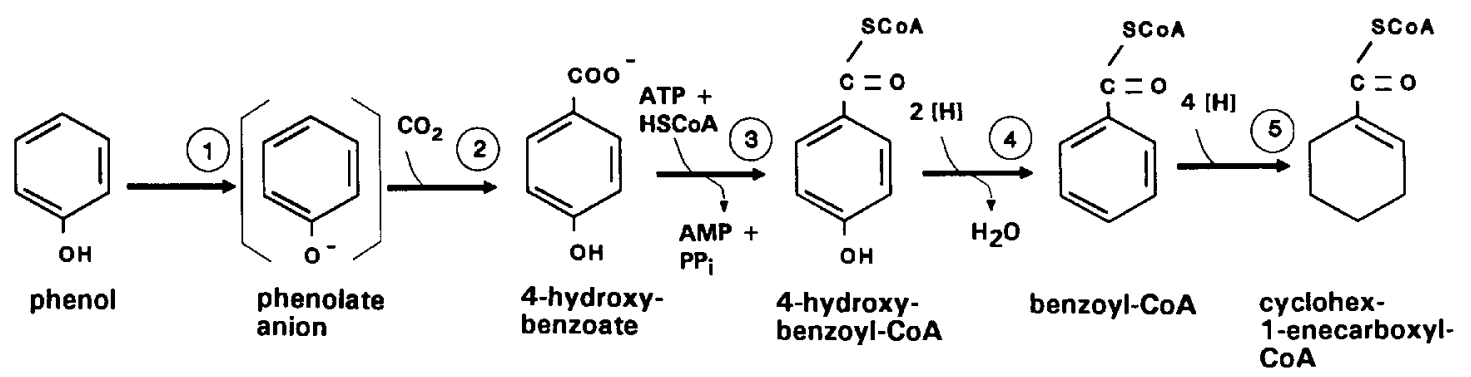

Fig. 2. Intermediates and enzymes involved in the initial steps of anaerobic phenol metabolism in the denitrifying Pseudomonas strain K 172. (1) and (2), Phenol carboxylase system; (3), 4-hydroxybenzoate-CoA ligase (AMP forming); (4), 4-hydroxybenzoyl-CoA reductase (dehydroxylating); (5), benzoyl-CoA reductase (aromatic ring reducing).

Although strictly anaerobic conditions prevail in several environmental compartments, up to now, biodegradation studies with emerging organic contaminants (EOCs), such as pharmaceuticals and personal care products, have mainly focused on aerobic conditions. One of the reasons probably is the assumption that the aerobic degradation is more energetically favorable than degradation under strictly anaerobic conditions. Certain aerobically recalcitrant contaminants, however, are biodegraded under strictly anaerobic conditions and little is known about the organisms and enzymatic processes involved in their degradation.

Ghattas et al. (2017) [16] provide a comprehensive survey of characteristic anaerobic biotransformation reactions for a variety of well-studied, structurally rather simple contaminants (SMOCs) bearing one or a few different functional groups. Furthermore it summarizes anaerobic degradation studies of more complex contaminants with several functional groups (CMCs), in soil, sediment and wastewater treatment. While strictly anaerobic conditions are able to promote the transformation of several aerobically persistent contaminants, the variety of observed reactions is limited, with reductive dehalogenations and the cleavage of ether bonds being the most prevalent. Thus, it becomes clear that the transferability of degradation mechanisms deduced from culture studies of SMOCs to predict the degradation of CMCs, such as EOCs, in environmental matrices is hampered due the more complex chemical structure bearing different functional groups, different environmental conditions (e.g. matrix, redox, $\mathrm{pH}$ ), the microbial community (e.g. adaptation, competition) and the low concentrations typical for EOCs.

Yonga and Zhong (2010) [17] provide an up-to-date review on progress in biodegradation research in China. They describe include the isolation of extremophilic microorganisms for pollutant degradation in extreme conditions and the study of genes and enzymes related to biodegradation pathways. Progress has been achieved in these fields, including the isolation of novel biodegradation microorganisms, elucidation of biodegradation pathways, innovation in biodegradation engineering, and generation of bioenergy from environmental waste. Biodegradation engineering has potential as an interesting and powerful platform, where genetic engineering, process engineering and signal transduction engineering are applied together. In addition, pollutant treatment combined with the production of renewable sources of bioenergy by microorganisms is attractive. 


\section{ENZYMES INVOLVED IN THE BIODEGRA- DATION OF PHENOLIC COMPOUNDS}

Generally aromatic compounds are broken down by natural bacteria. Derivatisation of aromatic nuclei with various substituents particularly with halogens makes them more recalcitrant. There are reports on many microorganisms capable of degrading phenol through the action of variety of enzymes. These enzymes may include oxygenases, hydroxylases, peroxidases, tyrosinases, oxidases etc. (Table 1).

Table 1. Enzymes involved in the biodegradation of phenolic compounds.

\begin{tabular}{|l|l|l|l|}
\hline \multicolumn{1}{|c|}{ Type of Phenol } & \multicolumn{1}{|c|}{ Reference } & \\
\hline Phenol & Phenol hydroxylase & Gurujeyalakshmi and Oriel (1988) & {$[18]$} \\
\hline Phenol & Polyphenol Oxidase & Burton et al. (1993) & {$[19]$} \\
\hline Phenol & Polyphenol Oxidase & Cano et al. (1997) & {$[20]$} \\
\hline Phenol & Phenol Oxidase & Okeke et al. (1997) & {$[21]$} \\
\hline Phenol & Polyphenol oxidase & Shashirekha et al. (1997) & {$[22]$} \\
\hline Phenol & 2,3 dioxygenase & Ali et al. (1998) & {$[23]$} \\
\hline Phenol & Laccase & Bollag et al. (1998) & {$[24]$} \\
\hline Phenol & Polyphenol oxidase & Garzillo et al. (1998) & {$[25]$} \\
\hline Phenol & Peroxidase & Ghioureliotis and Nicell (1999) & {$[26]$} \\
\hline Phenol & Horseradish peroxidase & Wu et al. (1998) & {$[27]$} \\
\hline Phenol & Horseradish peroxidase & Zahida et al. (1998) & {$[28]$} \\
\hline Phenol & Polyphenol oxidase & Edwards et al. (1999) & {$[29]$} \\
\hline Phenol & Laccase & Kadhim et al. (1999) & {$[30]$} \\
\hline Phenol & Laccase & Schneider et al. (1999) & {$[31]$} \\
\hline Methoxyphenol & Laccase & Setti et al. (1999) & {$[32]$} \\
\hline Phenol & Laccase & Hublik and Schinner (2000) & {$[33]$} \\
\hline Phenol & Laccase & Robles et al. (2000) & {$[34]$} \\
\hline Phenol & Catechol 1,2oxygenase & An et al. (2001) & {$[35]$} \\
\hline Phenol & Polyphenol oxidase & Luke and Burton (2001) & {$[36]$} \\
\hline Phenol & Peroxidase & Sakurai et al. (2001) & {$[37]$} \\
\hline Phenol & Polyphenol oxidase & Steffens (2002) & {$[38]$} \\
\hline Phenol & Phenol oxidase & Johjima et al. (2003) & {$[39]$} \\
\hline Phenol & Tyrosinase & Xiangchun and Zhang(2003) & {$[40]$} \\
\hline Lignophenols & Peroxidase & Xia et al. (2003) & {$[41]$} \\
\hline
\end{tabular}

\section{MICROORGANISMS IN THE BIODEGRA- DATION OF PHENOLIC COMPOUNDS}

Microorganisms are an important part of natural ecosystems. They are found in industrially contaminated soils and water as a result of their ability to survive in restrictive conditions. In this respect, their ability to rapidly and efficiently purify the environment of phenolic contamination is important, with a view to protecting the living environment and human health directly. A large number of aromatic compounds including phenol and phenol derivatives are difficult to dissolve and very dangerous due to their high toxicity. The study of key enzymes involved in aromatic catabolism is important from both a theoretical and a technological point of view since it can be aimed at the development of modern and effective treatment facilities [42, 43]. The application of molecular methods of analysis to the study of strains able to degrade hazardous chemical contaminants can lead to new approaches that will optimize the currently used technologies. The investigations on specificity of phenol biodegradation by different microbial strains are meaningful for the invention of effective remediation technologies for industrial wastes where the phenolic substrates are a common occurrence. Most of the current research has been directed at the isolation and study of microbial species of potential ecological significance.

In the review from Krastanov et al. (2013) [43], some of the best achievements in degrading phenolic compounds by bacteria and yeasts are presented, which draws attention to the high efficiency of strains of 
Pseudomonas, Candida tropicalis, Trichosporon cutaneum, etc. The unique ability of fungi to maintain their degradation potential under conditions unfavorable for other microorganisms is outstanding.
Degradation of phenol occurs as a result of the activity of a large number of microorganisms including bacteria, fungi and actinomycetes [5]. These microorganisms are presented in Table 2.

Table 2. Microorganisms in the biodegradation of phenolic compounds

\begin{tabular}{|c|c|c|c|}
\hline Type of phenol & Microorganisms & Reference & \\
\hline Phenol & Basidiomycota & Martinkov et al. (2016) & [44] \\
\hline Phenol & Rhodococcus & Martinkova et al. (2009) & [45] \\
\hline Phenol & Bacillus stearothermophilus & Gurujeyalakshmi and Oriel(1988) & {$[18]$} \\
\hline Phenol & Pseudomonas putida & Allsop et al. (1993) & [46] \\
\hline Phenol & Agaricus bisporus & Burton et al. (1993) & [19] \\
\hline Pentachlorophenol & Lentinus bisporous & Okeke et al. (1993) & [47] \\
\hline Phenol & Aerobic consortium & Ambujam and Manilal(1995) & [48] \\
\hline Phenol & Acinetobacter johnsonii & Hoyle et al. (1995) & [49] \\
\hline 2- cholrophenol & Pseudomanas putida & Over and Rehon (1995) & {$[50]$} \\
\hline Phenol & Pseudomonas $s p$ & Bodzek et al. (1996) & {$[51]$} \\
\hline Phenol & Pseudomonas $s p$ & Gotz and Reuss(1997) & {$[52]$} \\
\hline Penta, chlorophenol & Lentinula edodes & Okeke et al. (1997) & {$[21]$} \\
\hline Phenol & Ochromonas danica & Semple and Cain(1997) & [53] \\
\hline Phenol & Bacillus $s p$ & Shashirekha et al. (1997) & {$[22]$} \\
\hline Phenol & Phormidium valderianum & Ali et al. (1998) & [23] \\
\hline Phenol & Rhizoctonia praticola & Bollag et al. (1988) & {$[24]$} \\
\hline Phenol & Trametes trogii & Garzillo et al. (1998) & {$[25]$} \\
\hline Phenol & Pseudomonas putida & Loh and Wang (1998) & [54] \\
\hline Phenol & Pseudomonas flurorescens & Torres et al. (1998) & {$[55]$} \\
\hline Phenol & Pseudomonas putida & Mordocco et al. (1999) & {$[56]$} \\
\hline Phenol & Coriolus versicolor & Kadhim et al. (1999) & [30] \\
\hline Phenol & Ralstonia eutropha & Leonard et al. (1999 a,b) & {$[57,58]$} \\
\hline Phenol & Coprinus cinereus & Schneider et al. (1999) & {$[31]$} \\
\hline Phenol & Pseudomonas putida & Wang and Loh (1999) & {$[59]$} \\
\hline Phenol & Pseudomonas putida & Zumriye and Gultac (1999) & {$[60]$} \\
\hline Phenol & Pseudomonas pictorium & Annadurai et al. (2000a) & [61] \\
\hline Phenol, Nitrophenol & Nocardioides & Cho et al. (2000) & [62] \\
\hline Phenol & Phanerocheate chrysosporium & Garcia et al. (2000) & {$[63]$} \\
\hline Phenol & Pleurotus ostreatus & Hublik and Schinner (2000) & [33] \\
\hline Phenol & Pseudomonas putida & Loh and Tar (2000) & [64] \\
\hline Phenol & Acinetobacter calcoaceticus & Nakamura and Sawada (2000) & [65] \\
\hline Phenol & Chalara paradoxa & Robles et al. (2000) & {$[34]$} \\
\hline Phenol & Streptomyces setonii & An et al. (2001) & {$[35]$} \\
\hline Phenol & Alcaligenes $s p$ & Baek et al. (2001) & {$[66]$} \\
\hline Phenol & Pseudomonas $s p$ & Gonzalez et al. (2001) & [67] \\
\hline Phenol & Pseudomonas putida & Loh and Liu (2001) & [68] \\
\hline Phenol & Pseudomonas putida & Petruschka et al. (2001) & [69] \\
\hline Bisphenol & Coprinus cinereus & Sakurai et al. (2001) & [37] \\
\hline Phenol & Acinetobacter $s p$ & Hao et al. (2002) & [70] \\
\hline Phenol & Rhodococcus erythropolis & Prieto et al. (2002) & [71] \\
\hline Phenol & Trichosporon cutaneum & Godjevargova et al. (2003) & {$[72]$} \\
\hline Phenol & Termitomyces albuminosus & Johjima et al. (2003) & {$[39]$} \\
\hline 2, 4 dichlorophenol & Mixed culture & Quan et al. (2003) & {$[73]$} \\
\hline
\end{tabular}




\begin{tabular}{|l|l|l|l|}
\hline Chlorophenol & Pseudomonas putida & Farighian et al. (2003) & {$[74]$} \\
\hline Chlorophenol & Achromobacter $s p$ & Xiangchun et al. (2003) & {$[40]$} \\
\hline Phenol & Mixed Fungi & Atagana (2004) & {$[75]$} \\
\hline Phenol & Pseudomonas putida & Hamed et al. (2004) & {$[76]$} \\
\hline Phenol & Alcaligenes sp & Nair and Shashidhar (2004) & {$[77]$} \\
\hline Phenol & Fusarium sp & Santos and Linardi (2004) & {$[78]$} \\
\hline Pentachlorophenol & Sphingomonas chlorophenolica & Bielefeldt and Cort (2005) & {$[79]$} \\
\hline Dichlorophenol & Pseudomonas putida & Kargi and Eker (2005) & {$[80]$} \\
\hline Phenol & Pseudomonas sp & Prpich and Douglis (2005) & {$[81]$} \\
\hline Phenol & Bacillus brevis & Arutchelvan et al. (2006) & {$[82]$} \\
\hline Nonylphenol & Clavariopsis aquatica & Moeder et al. (2006) & {$[83]$} \\
\hline Phenol & Aspergillus awamori & Stoilova et al. (2006) & {$[84]$} \\
\hline Phenol & Candida tropicalis & Krastanov et al. (2013) & {$[43]$} \\
\hline Phenol & Pseudomonas & Belouhova et al. (2017) & {$[85]$} \\
\hline Phenol & Bacillus laterosporus & Topalova et al. (2011) & {$[86]$} \\
\hline Phenol & Pseudomonas rhodesiae & Satchanska et al. (2009) & {$[87]$} \\
\hline Phenol & Bacillus subtilis & Satchanska et al. (2015) & {$[88]$} \\
\hline Phenol & Candida tropicalis & Hristov et al. (2012) & {$[89]$} \\
\hline Phenol & Trichosporon montevideense & Hristov et al. (2012) & {$[89]$} \\
\hline Phenol & Pseudomonas sp. & Yotinov et al. (2016) & {$[11]$} \\
\hline
\end{tabular}

The phylum Basidiomycota include organisms with enormous bioremediation potential. A variety of processes were proposed at the lab scale for using these fungi and their phenol oxidases in the degradation of phenolics. Martinkov et al. (2016) [44] present a survey of this topic using literature published mostly over the last 10 years. Basidiomycota have a high potential for environmental technologies. Here the focus is on their use in the biodegradation of phenolic pollutants. The new trends in the production of their phenol oxidases are summarized.

Various forms of the catalysts (enzymes, whole cells) and reactors are compared. The perspectives of their industrial applications are discussed. Fungi of the phylum Basidiomycota are prominent tools for the degradation of recalcitrant pollutants [90] such as phenols, naphthols, bisphenols, phenolic or nonphenolic textile dyes, halogenated aromatics, polyaromatic hydrocarbons, etc. The focus of a review [44] is on the potential of these organisms, and especially their phenol oxidases, to degrade phenolics, which cause serious pollution of surface water, groundwater and soils [91].

A large number of aromatic compounds and organic nitriles, the two groups of compounds covered in this review from Prieto et al. (2002) [92]. They are intermediates, products, by-products or waste products of the chemical and pharmaceutical industries, agriculture and the processing of fossil fuels. The majority of these synthetic substances (xenobiotics) are toxic and their release and accumulation in the environment pose a serious threat to living organisms. Bioremediation using various bacterial strains of the genus Rhodococcus has proved to be a promising option for the clean-up of polluted sites. The large genomes of rhodococci, their redundant and versatile catabolic pathways, their ability to uptake and metabolize hydrophobic compounds, to form biofilms, to persist in adverse conditions and the availability of recently developed tools for genetic engineering in rhodococci make them suitable industrial microorganisms for biotransformations and the biodegradation of many organic compounds.

The genus Rhodococcus was soon regarded as one of the most promising groups of organisms suitable for the biodegradation of compounds that cannot be easily transformed by other organisms [93]. So far only pseudomonads and related bacteria have been reported to possess comparable biodegradation abilities.

Rhodococci are non-sporulating, aerobic bacteria classified into mycolate-containing nocardioform actinomycetes [94]. The genus Rhodococcus is comprised of genetically and physiologically diverse bacteria, which have been isolated from various habitats, for example soils and sea water. Since they are equipped with a large number of enzymatic activities, unique cell wall structure and suitable biotechnological properties, Rhodococcus strains may be utilized as industrial organisms, primarily for biotransformations and the 
biodegradation of many organic compounds [95]. Rhodococci can thus be applied in environmental remediation and in the pharmaceutical and chemical industries [96, 97]. The cell wall of rhodococci contains mycolic acids, like that of the genera Mycobacterium, Nocardia and Corynebacterium.

Cells of $R$. erythropolis immobilized on inorganic carriers (diatomaceous earth, zeolite) were found to be a suitable basis for an efficient phenol biodegradation process $[92,98]$.

Many studies on biodegradation of phenol come from bacteria. Bacterial species include Bacillus $s p$, Pseudomonas sp, Acinetobacter sp, Achromobacter $s p$ etc. The genus Pseudomonas is widely applied for the degradation of phenolic compounds. These bacteria are known for their immense ability to grow on various organic compounds. Phenol biodegradation studies with the bacterial species have resulted in bringing out the possible mechanism and also the enzyme involved in the process. The efficiency of the phenol degradation could be further enhanced by the process of cell immobilization [61, 99].

Fusarium sp, Phanerocheate chrysosporium, Corious versicolor, Ralstonia sp, Streptomyces sp etc are also proved to be efficient fungal groups in phenol biodegradation. However, these microorganisms suffer from substrate inhibition at higher concentration of phenol, by which the growth is inhibited [92].

The mycelium (or conidia) of Aspergillus awamori NRRL 3112 is investigated for its ability to degrade phenol, catechol, 2,4-dichlorophenol and 2,6-dimethoxyphenol in high concentrations. The biodegradation studies were performed in a liquid medium with the phenolic compounds as a sole carbon and energy source [84]. The organism had mineralized phenol concentration of $0.3 \mathrm{~g} / 1$ in $60 \mathrm{~h}$, $0.6 \mathrm{~g} / 1$ in $72 \mathrm{~h}$ and $1.0 \mathrm{~g} / 1$ in $7-8$ days. Successfully simulated phenols degradation profiles in all studies are obtained by Haldane-type kinetics. Besides, such mathematical models could successfully be used to predict the rate of phenols biodegradation under industrial conditions. The values of endogenous or decay and yield coefficients for all phenols at different concentrations are also determined.

\section{IMMOBILIZATION}

\section{IMMOBILIZATION IN POLYACRYLONITRILE (PAN) GRANULES}

The ability of Trichosporon cutaneum R57 to grow on and utilize some toxic compounds (phenol, acetophenone, acetone, amethylstyrene, benzoic acid, dimethyl phenyl carbinol, methanol and isopropylbenzene) as sole carbon and energy sources is studied. The growth of $T$. cutaneum R57 in a model solution including all the contaminants mentioned above is studied and results are compared with growth curves in two types of waste water taken from the basin of the biopurification station with active sludge, treating water from oil refinery (Lukoil-Neftochim Co. (Bourgas, Bulgaria)) and some accompanying organic products facilities, including waste water from industrial phenol production [72]. The strain is found to grow well in both types of waste water (inlet and outlet of the biobasin) and in the model solution. The results showed that strain $T$. cutaneum $R 57$ can utilize a wide range of toxic compounds simultaneously.

For the study of immobilized cells [100], $2 \mathrm{~g}$ porous polyacrylonitrile (PAN) granules are prepared by dissolving $18 \mathrm{~g}$ PAN (product of Neftochim, Bulgaria), $1 \mathrm{~g} \mathrm{LiNO}_{3}$ and $3 \mathrm{~g}$ glycerol in $78 \mathrm{ml}$ of dimethylformamide (DMFA). The homogenized mixture was pipetted and precipitated in water. The granules obtained are washed with distilled water and immersed in a $30 \%$ aqueous solution of glycerol for $24 \mathrm{~h}$ and they dried at $70^{\circ} \mathrm{C}$ to constant weight.

The immobilized system had high vitality and adaptivity into waste water from phenol production. The highest degradation after $24 \mathrm{~h}$ is observed for acetone $(50-60 \%)$, benzoic acid is reduced by 25 $140 \%$ and phenol and dimethyl phenyl carbinol approximately by $30-45 \%$ depending on the type of the cells. Immobilized cells are showed a higher ability to degrade the more toxic compounds compared to free cells [72]. The results obtained indicate the ability of T. Cutaneum R57 to degrade some of the most toxic contaminants present in waste water.

\section{IMMOBILIZATION IN POLYETHYLENE OXIDE CRYOGELS (PEO-CRYOGEL)}

In recent years different organic carriers for bacterial immobilization were investigated. Among the synthetic polymers, poly(ethylene oxide) hydrogels are excellent candidates because they are nontoxic biocompatible materials which meet all of the requirements of strength, absorbency, exibility and adhesiveness. In the study by Satchanska et al (2009) [87] macroporous poly(ethylene oxide) PEO cryogels were investigated as carriers of xenobiotics degrading bacteria and the obtained PEO-biofilms were investigated for their ability for phenol biodegradation. 


\section{CRYOGELS PREPARATION:}

High molecular weight poly(ethylene oxide) (Union Carbide; $\mathrm{MW}=2.106 \mathrm{~g} / \mathrm{mol}$ ) was dissolved in distilled water (5 wt.\%) and then a photo initiator (4-benzoylbenzyl) trimethylammonium chloride (Aldrich; 2 wt.\% with respect to the polymer) was added under stirring at room temperature. The resulting homogeneous solution was poured into Teflon dishes (50 mm diameter) forming a $2.5 \mathrm{~mm}$ thick layer, which was then kept in a freezer at a temperature of $-20^{\circ} \mathrm{C}$ for $2 \mathrm{~h}$. The dishes were quickly placed in a thermostatic open chamber connected with a Julabo cryostat apparatus. The frozen system was irradiated with full spectrum UVVIS light at $-20^{\circ} \mathrm{C}$ with a Dymax 5000-EC UV curing equipment with $400 \mathrm{~W}$ metal halide flood lamp for $2 \mathrm{~min}$ (dose $-11.4 \mathrm{~J} / \mathrm{cm} 2$; input power $93 \mathrm{~mW} / \mathrm{cm} 2$ ). The PEO cryogels were extracted in distilled water for seven days, quickly frozen in liquid nitrogen and freeze dried in an Alpha 1-2 Freeze Drier (Martin Christ) at $-55^{\circ} \mathrm{C}$ and $0.02 \mathrm{mbar}$ for $24 \mathrm{~h}$. The gel fraction (GF) yield was calculated by the following equation:

GF yield [\%] $=($ weight of dried sample/initial weight of polymer) $\times 100.2$.

The study by Satchanska et al. (2015) [88] show the phenol-degradation performance of a promising new environmentally friendly biomaterial that was constructed and investigated for its biodegradation capability. The biofilter is cheap, highly effective and could be potentially useful in industrial wastewater treatment. Two xenobiotic-degrading bacteria are isolated from industrial areas polluted with heavy metals and aromatics. The studied microbial isolates were cultured from polluted soil near the $\mathrm{Pb}-\mathrm{Zn}$ smelter called $\mathrm{KCM}$ (strain $\mathrm{KCM}$ R5) and from groundwater collected near the pesticide producing factory AGRIA (KCM RG5). Both manufactories are situated at a distance of about $6 \mathrm{~km}$ from the town of Plovdiv, Bulgaria. The $\mathrm{Pb}-\mathrm{Zn}$ smelter is the biggest one on the Balkan Peninsula. AGRIA factory is manufacturing more than 50 various pesticides.

Sequencing of xenobiotic-degrading bacteria 16S rDNA classified them as Pseudomonas rhodesiae (denoted as KCM R5) and Bacillus subtilis (denoted as KCM RG5).

The cryogels demonstrated non-toxicity, high biocompatibility with bacteria and excellent mechanical characteristics. PEO cryogels showed high biocompatibility with xenobiotics degrading bacterial strains KCM R5 and KCM RG5. The PEO-
KCM R5 biofilter was found to remove phenol at a concentration of $1000 \mathrm{mg} / \mathrm{L}^{-1}$, while the PEO-KCM RG5 system was unable to degrade phenol at a concentration of about $600 \mathrm{mg} / \mathrm{L}^{-1}$. After four weeks of biodegradation, the PEO biofilms remained compact, porous and elastic, while containing compact microbial biofilm as shown by scanning electron microscopy analysis of the cryogels.

Immobilization of the Bacillus laterosporus BT271 microbe culture is described by Topalova et al. (2011) [86]. A long (20 days) model process of phenol biodegradation was performed in biofilters in sequencing batch regime and with active biological system - polyethylene oxide cryogels (PEO-cryogel) with immobilized bacteria Bacillus laterosporus BT271. The model waste water, containing mineral medium and phenol as the only source of carbon and energy with $300 \mathrm{mg} / \mathrm{l}$ in the effluent, was used One of the key investigated parameters was the manner of immobilization of the bacteria in polyethylene oxide cryogels. The two variants of the experiment were carried: direct immobilization of the inoculation material (SBB-D) and inoculation of the biomass after preliminary separation and further concentration (SBB-S) [86]. The implantation of the gel with the immobilized microorganisms in a sequencing batch biofilter showed good biodegradation, kinetic, enzymological characteristics, as well as self-renovating adequate biofilm structure in laboratory conditions. The two biofilters functioned well and the efficiency of phenol elimination reached $100 \%$ in 15 days. The variant SBB-D showed a more stable process, as well as an easier way of preparing the initial PEO-plate biofilm. The SBB-D system is suitable for scaling and future implementation of the water purification processes in practice.

All obtained results show that bacterial culture Bacillus laterosporus $B T-271$ is suitable for immobilization in PEO-gel. The formed biofilm is stable and after a 15-day adaptation period shows steady biodegradation activity. More stable variant for immobilization of the microbe biomass is the direct soaking of the PEOplate in the preliminarily multiplied bacterial culture, variant SBB-D. The implantation of the gel with the immobilized microorganisms in a sequencing batch biofilter shows good biodegradation, kinetic, enzymological characteristics, as well as self-renovating adequate biofilm structure in laboratory conditions. The SBB$\mathrm{D}$ system is suitable for scaling and future implementation of the water purification processes in practice 


\section{IMMOBILIZATION OF YEAST ASSOCIATION}

The study by Hristov et al. (2012) [89] demonstrated the phenol degrading potential of yeast association consisting of two strains identified as Candida tropicalis and Trichosporon montevideense. At initial phenol concentration of $0.5 \mathrm{~g} .1^{-1}$ the process was carried out in semicontinuous mode using cells of microbial association, free and immobilized on three different carries (Ca-alginate, zeolite and polyether-polyurethane (PUF)). The removal efficiency of phenol by free and immobilized cells, the influence of a mixture of five heavy metals $(\mathrm{Cu}, \mathrm{Mn}, \mathrm{Co}, \mathrm{Ni}, \mathrm{Zn})$ on the biodegradation process were reported. The experimental results indicated that both cells, free suspended and immobilized in Ca-alginate, showed high phenol degrading efficiencies within $144 \mathrm{~h}$, but the immobilized cells showed better performance in the presence of heavy metals compared to that of the suspended cells.

\section{IMMOBILIZATION OF PENOPOLY- STYROL PELLETS, COVERED WITH ACTIVE CARBON}

Two steps of enhancement of phenol detoxification by Bacillus laterosporus BT-2 71 by means of increasing of the rate of aeration and adding in an apropriate moment a carrier ( penopolystyrol pellets, covered with active carbon ) were studied from Topalova et al. (1995) [101]. The investigated bacterium was isolated from phenol polluted soil in the region of the petrochemical plants near Bourgas (Bulgaria). The strain was subjected to laboratory selective adaptation towards high phenol concentrations. Phenol was added after sterilization in a concentration $6.96 \mathrm{mmol}$. The innoculation of the reactor was being done with a 23-hour innoculation material. The carrier (30\% vol.) was put in bioreactor at a chosen optimum aeration regime. It was in the form of penopolystyrol pellets foamed to a density of $500 \mathrm{~kg} / \mathrm{m}^{3}$, diameter - $2.0+0.2 \mathrm{~mm}$, whose surface was activated by covering with layers of active carbon. Comparative study of the oxygenase activities of the freely suspended cells at the two steps of speeding up of the phenol elimination to elucidate the mechanisms of the processes was carried out. The effectiveness of phenol biodegradation was enhanced with $42 \%$.
NEW TECHNOLOGY

\section{FISH (FLUORESCENCE IN-SITU HYBRIDIZATION)} ANALYSIS

The main governing factors in the biodetoxification technologies are the concentration of xenobiotic pollutants in dependence of critical one as well as the way of its inflow in the system gradually or shock loading. The aim of the study from Belouhova et al. (2017) [85] is to investigate the key differences in adaptation mechanisms of $1 /$ sediment biofilm, subjected to shock loading of toxic pollutant (phenol)2/ biofilm community, that is purposefully adapted to the increased xenobiotic concentration (amaranth) The adaptive changes in two biofilm communities from lab-scale biodetoxifcation technologies were estimated and compared on the base of functional and microbiological parameters. The processes were studied in two analogous models - case studies. Case study 1 - bioremediation of sediments from Iskar river with shock phenol loading in concentration three times higher than critical one, that is about $250 \mathrm{mg} / \mathrm{g}$ sediment; Case study 2 laboratory sand biofilter - treating amaranth polluted wastewater. The inoculation material was specially treated activated sludge, taken from Sofia WWTP (wastewater treatment plant). The biofilter was supplied with highly specialized adaptive algorithm for gradually increase of xenobiotic concentration (from 5 to $50 \mathrm{mg} / \mathrm{L}$ amaranth).

Two detoxification technologies have been compared according to: key technological and microbiological parameters, the micro-distribution and the role of unculturable microorganisms as well as the microbial relationships in genus Pseudomonas. The special attention has been paid on the analysis of the polyphosphates as an indicator for the alternative energetic sources polyhydroxyacetate and poyhydroxybutyrate. In the study new fluorescent method FISH (Fluorescence In-Situ Hybridization) was used. The fluorescence in-situ hybridisation is one of the most widely used methods for studying the biofilms, involved in water purification and detoxification processes This molecular techniques gives information about the quantitative and qualitative composition and spatial distribution of microorganisms in communities.

A fluorescence in-situ technique, particularly suitable for the study of biofilms, is coloring of the polyphosphate granules with DAPI (4',6-diamidino2-phenylindole). It is known that when DAPI bonds to the polyphosphate granules the maximum of 
emission of the dye changes, and its color instead of blue looks yellowgreen [102]. In the biological purification of waters with microbial elimination of phosphates the technologies are based on the accumulation of polyphosphates (metachromatin) in the bacterial cells. These bacterial inclusionsare directly connected with the synthesis and using of poyhydroxybutyrate and polyhydroxyacetate granules. These granules can be used as alternative sources of energy. In the extreme difficult conditions of availability of high concentration of xenobiotics the using of the alternative sources of energy by microorganisms can play indicative role for an adaptation to the biodegradation of the xenobiotics. The reason is that the xenobiotics affect negatively the electron transport and oxidative phosphorylation and inhibit the synthesis of ATP [103, 104]. By investigation of the amount and localization of polyphosphates and the related use of reserve carbon sources it is possible to detect the degree of adaptation of the microbial community to xenobiotic biodegradation.

The results from Belouhova et al. 2017 [85] showed that the technology with shock xenobiotic load reached the effectiveness of xenobiotic elimination $28 \%$, while the technology with adaptive algorithm - $89 \%$. As general conclusion the adaptation mechanisms towards xenobiotic biodegradation were different on the base of ways of inflow of the toxicants in the technology. After the shock xenobiotic loading in concentration three times higher than critical the biofilm developed the most simple mechanism - the multiplying of the microorganisms, but the biodegradation effectiveness was low. After application of the purposely constructed adaptive algorithm, microbial communities developed complex mechanisms of azo-detoxification, included the increased role of unculturable bacteria and synergistic relationships between them. This leaded to the increased effectiveness of xenobiotic detoxification. At concentrations of the toxicant exceeding the critical ones the microbial community was dependent to a larger extent on reserve sources of energy and adaptation took place mostly on the basis of an increase the number of culturable biodegraders.

\section{NANOBIOTECHNOLOGIES}

Nanobiotechnologies are a rapidly growing field that offers new opportunities thus far unknown including regulation processes at a nano level. The biodetoxification and mechanisms of degradation of many xenobiotics have been studied and are well documented. There remains the important issue of the impact of nanomodulators on biodetoxification processes and their potential to optimize and regulate biodegradation of recalcitrant xenobiotics. Carbon nanoparticles, which include nanodiamonds (ND), are used in a number of technological and medical applications. It is investigated the effect of ND on the biodegradation of phenol in model conditions [11]. The process of degradation was realized with a microbial culture of Pseudomonas $s p$. isolated from contaminated sediments in the small reservoir Lakatnik. It is a part of the Middle Iskar cascade (Bulgaria). It was found that ND have a stimulating effect on the initial phase of biodegradation of phenol. ND in concentrations of $100 \mathrm{ppm}$ added at the start of the process led to an increase a lot of important parameters of biological detoxification - specific rate of phenol biodegradation, effectiveness of phenol biodegradation and oxygenase enzyme activities and shorten the biodetoxification. The results show that the ND affected in a different way the activity of inductive and constitutive oxygenases. The application of ND has a high potential for the management of microbial biodegradation and enhancement of the effectiveness of detoxification technologies for sediments and wastewater contaminated with xenobiotics.

The purpose of the study by Yotinov et al. (2017) [105] is to clarify in comparative terms the effect of carbon nanoparticles (single-walled nanotubes (SWNT) and nanodiamonds (ND)) on these processes. It is a new mechanism for regulation of detoxification processes included in the industrial wastewater treatment. In order to achieve this objective analogous modeling of biodegradation processes is performed. The experiment are conducted in simplified conditions, using a microbial culture of Pseudomonas sp. [105]. It was observed the influence of ND and SWNT on the basic kinetic parameters and key oxygenase enzymes of the bacteria from the genus Pseudomonas. ND have a positive regulating effect regarding the detoxification of phenol at the initial stages of the process. SWNT show weaker augmentation effect but lasting during the whole detoxification process, which is seen from the high values of the inductive enzyme. ND increase the activities of phenol-2-monooxygenase and catechol2,3 -dioxygenase respectively by $63,91 \%$ and $63,94 \%$ in comparison to the control variant. Under the same conditions SWNT have positive influence on the catechol-1,2-dioxygenase activity by $30,12 \%$ in comparison to the control. Depending on the 
conditions of the wastewater treatment process both nanomodulators can be used purposely for regulating the biological detoxification. ND are more applicable in the risk situation of shock loading of industrial waters with xenobiotic pollutants to overcome the initial high toxic effect of phenol and its derivatives. The SWNT are more appropriate for long lasting detoxification processes to sustain the constant rate of the detoxification.

\section{MOLECULAR DOCKING}

Molecular docking is a method which finds out the preferred orientation of one or more molecules in the active sites of proteins [106]. Liu et al. (2018) [107] wrote a review for the application of molecular docking between organic pollutants and enzymes. They summarize the fundamental knowledge of molecular docking, such as its theory, available softwares and main databases. Moreover, five types of pollutants, including phenols, BTEX (benzene, toluene, ethylbenzene and xylenes), nitrile, polycyclic aromatic hydrocarbons (PAHs) and high polymer (e.g., lignin and cellulose), are discussed from molecular point of view. Different removal mechanisms are also explained in detail via docking technology. Even though this method shows promising application in the research of biodegradation, further studies are still needed to relate with actual condition.

Moreover, usually one kind of microorganism such as Pseudomonas sp., Acinetobacter sp., Nocardia globerula sp., Bacillus sp., Phanerochaete $s p$. and Trametes sp. could convert and decompose several organic compounds due to the secretion of a variety of enzymes. Actually, enzymes are the main reactants in the process of biodegradation. In order to study the interactions between enzyme and phenol at the molecular level, some simulation technology has been adopted. Nowadays, with the development of science and software technology, molecular docking approach has been used to analyse the interactions between substrates and enzymes, such as laccase with phenol [91].

\section{CONCLUSION}

Commercial enzymes have been useful for designing the basic principles of potential industrial processes, but the large-scale use of these preparations seems to be prohibitive because of their high costs. For this purpose, inexpensive fungal biomasses from solid-state cultures are more attractive. The combination of fungal mycelia and enzymes with other physico-chemical or biological agents such as chemical oxidation and activated sludge are also promising for scale-up. The published studies also demonstrate the necessity of analysing the reaction products, assessing their potential toxicity and working out the processes for their efficient post-treatment removal.

During the past few years, researchers have focused on the removal efficiency of contaminants by controlling and adjusting reaction condition, less mentioned deeper reason such as the transformation of enzymes.

The immobilized system had high vitality and adaptivity into waste water from phenol production. In recent years different organic carriers for bacterial immobilization were investigated. Among the synthetic polymers, poly(ethylene oxide) hydrogels are excellent candidates because they are nontoxic biocompatible materials which meet all of the requirements of strength, absorbency, exibility and adhesiveness. The immobilized cells showed better performance in the presence of heavy metals $(\mathrm{Cu}$, $\mathrm{Mn}, \mathrm{Co}, \mathrm{Ni}, \mathrm{Zn}$ ) compared to that of the suspended cells.

FISH (fluorescence in-situ hybridization) analysis leaded to explain the increased effectiveness of xenobiotic detoxification. At concentrations of the toxicant exceeding the critical ones the microbial community was dependent to a larger extent on reserve sources of energy and adaptation took place mostly on the basis of an increase the number of culturable biodegraders.

Nanobiotechnologies are a rapidly growing field that offers new opportunities thus far unknown including regulation processes at a nano level. There remains the important issue of the impact of nanomodulators on biodetoxification processes and their potential to optimize and regulate biodegradation of recalcitrant xenobiotics. Hanodiamonds are more applicable in the risk situation of shock loading of industrial waters with xenobiotic pollutants to overcome the initial high toxic effect of phenol and its derivatives.

The review [20] has mainly demonstrated that molecular docking is a promising method. Molecular docking was widely used in many research fields by virtue of its convenience and low cost. Especially, molecular docking is able to predict and account for the mechanism of biological reaction. 


\section{FUTURE RESEARCH}

Over the years, our understanding of biodegradation has been improved significantly. All of the studies outlined above are significant for exploring efficient and sustainable biological processes for the clean up of pollutants. The optimization of the substrate concentration in phenol biodegradation is particularly important since it inhibits the growth of the organism at higher concentrations. Biotechnology for hazardous waste management involves the development of biological systems that catalyse the detoxification, degradation or decontamination of environmental pollutants.

It is important to understand the behaviour and ecotoxicity of phenols. Future studies should focus on four aspects as follows: firstly, research into the ecotoxicity of phenols to marine systems should be strengthened given the current lack of data and its irreplaceability by data pertaining to freshwater organisms. Secondly, it is necessary to isolate marine organisms that have the ability of degrading phenols of high solubility in water. Thirdly, joint toxicity of mixed chemicals needs more attention for the lack of data. Finally, the mechanisms of action of phenols on freshwater and marine organisms warrants further study. Sensitive biomarkers should be screened, as this is deemed conducive to improved ecotoxicological assessment and monitoring in aquatic systems.

More effort should be made to explore new microorganisms, enzymes, genes, and to elucidate new biodegradation pathways, mechanisms and applications of process engineering, as well as the effects of signal transduction. Investigation of bioenergy from wastes is at an early stage, and more attention should be paid to investigation of its mechanisms and to its field-scale application.

In summary, biodegradation is still attracting technology for environmental pollutant treatment; the successes of biodegradation will encourage us to further unveil these processes and to explore more efficient and cost-effective biodegradation processes.

\section{ACKNOWLEDGEMENTS}

This work was supported under project DN 17/4. The authors would like to thank the National Science Fund, Ministry of Education and Science of the Republic of Bulgaria.

\section{REFERENCES}

1. Duana W., Menga F., Cuia H., Linc Y.,Wangc G., Wuc J., Ecotoxicity of phenol and cresols to aquatic organisms: A review, Ecotoxicology and Environmental Safety 157, 2018, 441-456.

2. Hattenschwiler, S., Vitousek, P.M., The role of polyphenols in terrestrial ecosystem nutrient cycling. Trends Ecol. Evol. 15, 2000, 238-243.

3. Khoddami, A., Wilkes, M.A., Roberts, T.H., Techniques for analysis of plant phenolic compounds. Molecules, 18, 2013, 2328-2375

4. Gianfreda, L., Sannino, F., Rao, M.A., Bollag, J.M.,Oxidative transformation of phenols in aqueous mixtures. Water Res. 37, 2003, 3205-3215.

5. Nair, C.I., Jayachandran, K., Shashidhar, S., Biodegradation of phenol. Afr. J. Biotechnol. Vol. 7 (25), 2008, 4951-4958.

6. Amp, M., The merck index : an encyclopedia of chemical, drugs, and biologicals, 1996.

7. China Chemical Safety Association,.Canned car accident caused phenol leakage into Xin'an River in Zhejiang Province. Available at: 〈http://www.chemicalsafety.org.cn/

detail.php?Oneid=5368) (in Chinese), 2011.

8. HELCOM,.Response to Accidents at Sea Involving Spills of Hazardous Substances and Loss of Packaged Dangerous Goods. Baltic Marine Environment Protection Commission, Finland, 2002.

9. Wei, X., Gilevska, T., Wetzig, F., Dorer, C., Richnow, H.H., Vogt, C., Characterization of phenol and cresol biodegradation by compound-specific stable isotope analysis. Environ. Pollut. 210, 2016, 166-173.

10. Topalova Y., Todorova Y., Schneider I., Yotinov I., Stefanova V., Detoxification potential and rehabilitation of activated sludge after shock loading of Sofia's wastewater treatment plant 'Kubratovo' with mazut, Water Science \& Technology, 78, 3, 2018, 588-601

11. Yotinov, I., Y. Todorova, I. Schneider, E. Daskalova, Y. Topalova, The effect of nanodiamonds on phenol biodegradation by Pseudomonas sp. strain isolated from polluted sediments, Journal of Nanoscience and Nanotechnology, 16, 2016, 76967706.

12. Das, N. ,Chandran P., Microbial degradation of petroleum hydrocarbon contaminants: an overview., Biotechnology Research International, 2011, 1-13.

13. Hernández-López, E. , Ayala, M., VazquezDuhalt, R., Microbial and enzymatic 
biotransformations of asphaltenes., Petroleum Science and Technology, 33, 9, 2015, 1017-1029.

14. Topalova, Y. , 2009, Biological control and management of water treatment, Publish Sci-Set Eco, Sofia, Bulgaria, 2009.

15. Lack A., Fuchs G., Carboxylation of phenylphosphate by phenol carboxylase, an enzyme system of anaerobic phenol metabolism in a denitrifying Pseudomonas sp., Journal Bacteriol., 174, 1992, 3629-3636.

16. Ghattas A., Fischer F.Wick A., Ternes T., Anaerobic biodegradation of (emerging) organic contaminants in the aquatic environment, Water Research, 116, 2017, 268-295.

17. Yonga Y., Zhong J. Recent advances in biodegradation in China: New microorganisms and pathways, biodegradation engineering, and bioenergy from pollutant biodegradation, Process Biochemistry, 45, 2010, 1937-1943.

18. Gurujeyalekshmi G, Oreil P Isolation of phenol degrading Bacillus stearothermophilus and partial characterization of the phenol hydroxylase. Appl. Environ. Microbiol. 55(2), 1988, 500-502.

19. Burton SG, John RD, Perry TK, Peter DR, Activity of mushroom polyphenol oxidase in organic medium, Biotechnol. Bioeng. 42, 1993, 938-944.

20. Cano PM, Begona de Ancos, Gloria LM, Mariana S., Improvement of Frozen banana (Musa cavendisher, C. Venana) colour by blanching: relationship between browning, phenols and polyphenol oxidase and peroxidase activities, European Food Research and Technology, 204 (1), 1997, 60-65.

21. Okeke BC, Paterson A, Smith JE, Watson CIA Comparative biotransformation of pentachlorophenol in soils by solid substrate cultures of Lentinula edodes. Appl. Microbial. Biotechnol., 48, 1997, 563-569.

22. Shashirekha S, Uma L, Subramanian G., Phenol Degradation by the marine cyanobacterium Phormidium valderianum BDU 30501, J. Ind. Microbiol. Biotechnol., 19, 1997, 130-133.

23. Ali S, Roberto F, La fuente, Dona AC., Meta pathway degradation of phenolics by thermophilic Bacilli. Enzyme Microbial Technol., 23, 1998, $462-$ 468.

24. Bollag JM, Shuttle WKN, Anderson DH., Laccase mediated detoxification of phenolic contaminants. Appl. Environ. Microbiol., 54(12), 1988, 3086-3091.

25. Garzillo AMV, Colao MC, Caruso C, Caporate C, Celletti D, Buonocore V., Laccase from the white rot fungus Trametes trogii. Appl. Microbiol. Biotechnol. 49, 1998, 545-551.

26. Ghioureliotis M, Nicell J., Assessment of soluble products of peroxidase catalysed polymerisation of aqueous phenol., Enzyme Microbial. Technol., 25, 1999, 185-193.

27. Wu Y, Keith FT, Nihar B, Jatinder KB., A model for the protective effect of additives on the activity of horseradish peroxidase in the removal of phenol, Enzyme Microbial Technol., 22, 1998, 315322 .

28. Zahida Deva W, Gulam M, Peerzuda MD, Diagambar VB., Oxidation of phenols by horseradish peroxidase and lactoperoxidase compound II. Kinetic consideration, 35, 1998, 353-357.

29. Edwards W, Bowness R, Leukes WD, Jacobs EP, Sanderson R, Rose PD, Burton SG., A capillary membrane reactor using immobilized polyphenol oxidase for the removal of phenols from industrial effluents, Enzyme Microbial Technol., 24, 1999, 209-217.

30. Kadhim H, Graham C, Baratt P, Evane CS, Rastall RA., Removal of Phenolic compounds by Coriolus versicolor grown on wheat bran, Enzyme Microbial Technol., 24, 1999, 303-307.

31. Schneider P, Michael BC, Kristine M, Torben, Lars KS, Peter RO, Kiberly MB, Stephen HB, Feng X., Characterization of a Coprinus cinereus laccase. Enzyme microbial Technol., 25, 1999, 502-508.

32. Setti L, Silvia G, Giovanni S, Pier GP., Laccase catalysed oxidative coupling of 3-methyl 2 benzothiazolenone hydrazone and methoxyphenol. Enzyme Microbial Technol., 25, 1999, 285-289.

33. Hublik G, Schinner F., Characterization and immobilization of the laccase from Pleurotus ostreatus and its use for the continuous elimination of phenolic pollutants.,Enzyme Microbial Technol., 27, 2000, 330- 336 .

34. Robles A, Lucas R, Cienfueges AD, Galvez., A Phenol oxidase activity in strains of the hyphomycete Chalara paradoxa isolated from Olivemill wastewater disposal ponds, Enzyme Microbial Technol., 26, 2000, 484- 490.

35. An H, Park H, Kim E., Cloning and expression of thermophilic catechol 1,2 dioxygenase gene (cat A) from Streptomyces setonii., FEMS Microbiol. Lett., 195, 2001, 17-22.

36. Luke AK, Burton SG., A novel application for Pseudomonas putida progress from batch culture to a membrane bioreactor for the bioremediation of phenols, Enzyme Microbial Technol., 29, 2001, 348-356. 
37. Sakurai A, Toyoda S, Sakakibar S., Removal of bisphenol A by polymerization and precipitation method using Coprinus cinereus peroxidase, Biotechnol. Lett., 23, 2001, 978-995.

38. Steffens LJC., Over expression of polyphenol oxidase in transgenic tomato plants results in enhanced bacterial disease resistance, Planta, 215, 2002, 239-247.

39. Johjima T, Ohkuma M, Kudo T., Isolation and cDNA cloning of novel hydrogen peroxide dependent phenol oxidase from the basidiomycete Termitomyces albuminosus, Appl. Microbiol. Biotechnol., 64, 2003, 220-225.

40. Xiangchun Q, Zhang YM., Biodegradation of 2,4 dichlorophenol in an airlift honeycomb like ceramic reactor. Proc. Biochem., 38, 2003, 15451551 .

41. Xia Z, Yoshida T, Fonuoku M., Enzymatic degradation of highly phenolic lignin based polymers (lignophenols), Eur. Polymer J., 39, 2003, 909- 914.

42. Topalova, Y., Biological control and management of water treatment, Publish Sci-Set Eco, Sofia, Bulgaria, 2009.

43. Krastanov A., Alexieva Z., Yemendzhiev H., Microbial degradation of phenol and phenolic derivatives, Eng. Life Sci., 13, 2013, 76-87.

44. Martínkov L., Kotik M, Markov E.,Homolka L., Biodegradation of phenolic compounds by Basidiomycota and its phenol oxidases: A review, Chemosphere, 149, 2016, 373-382.

45. Martínková L., Uhnáková B.,Pátek M.,Nešvera J., Křen V., Biodegradation potential of the genus Rhodococcus, Environment International, 35, 2009, 162-177.

46. Allsop PJ, Chisti Y, Moo-Young M, Sullivan GR, Dynamics of phenol degradation by Pseudomonas putida. Biotechnol. Bioeng. 41, 1993, 572-580.

47. Okeke BC, Smith JE, Paterson, Watson, Cruicle IA Aerobic metabolism of penta chlorophenol by spent sawdust of shitake mushroom (Lentinus edodes) in Soil, Biotechnol. Lett. 15(10), 1993, 1077- 1080.

48. Ambujam S, Manilal VB, Phenol degradation by a stable aerobic consortium and its Bacterial isolation, Biotechnol. Lett. 17(4), 1995, 443-448.

49. Hoyle BL, Scow KM, Fogg GE, Darby JL., Effect of carbon/nitrogen ratio on kinetics of phenol biodegradation by Acinetobacter johnsonii in saturated sand, Biodegradation, 6(4), 1995, 283293.
50. Over MC, Rehon HJ, Biodegradation of 2chloroethanol by freely suspended and adsorbed immobilized Pseudomonas putida 11S2 in soil, Appl. Microbiol. Biotechnol, 43, 1995, 143-149.

51. Bodzek M, Jolanta B, Malgorzata K, Immobilized enzyme membranes for phenol and cyanide decomposition, J. Membrane Sci., 113, 1996, 373-384.

52. Gotz P, Reuss M., Dynamics of microbial growth: modeling time delays by introducing polymerization reaction. J. Biotechnol., 58, 1997, 101-114.

53. Semple KT, Cain RB, Degradation of phenol and its methylated homologies by Ochromonas danica. FEMS, Microbiol. Lett., 152, 1997, 133-139.

54. Loh K, Wang S., Enhancement of phenol and a nongrowth substrate 4-chlorophenol by medium augmentation with conventional carbon sources, Biodegradation, 8, 1998, 329-338.

55. Torres LG, Alicia Sanchez de-la-vega Norma A, beltran KB, Jimmenz Production and characterization of calcium alginate biocatalyst for removal of phenol and chlorophenols from waste waters. Proc. Biochem., 33(6), 1998, 625-634.

56. Mordocco A, Clern K, Roger J., Continuous degradation of phenol at low concentration using immobilized Pseudomonas putida. Enzyme Microbial Technol., 25, 1999, 530-536.

57. Leonard D, Lindly NA, Growth of Ralstonia eutropha on inhibitory concentration of phenol: Diminished Growth can be attributed to hydrophilic perturbation of Phenol hydroxylase activity. Enzyme Microbial Technol. 25, 1999a, 271-277.

58. Leonard D, Ben CY, Destnehaut C, Lindley ND, Queinnec I., Phenol degradation by Ralstonia eutropha, calorimetric determination of 2hydroxymuconic semialdehyde accumulation by fed batch fermentation, Biotechnol. Bioeng., 65(4), 1999b, 407-414.

59. Wang Si-Jing, Loh, KC., Modeling the role of metabolic intermediates in kinetics of phenol biodegradation, Enzyme Microbial Technol., 25, 1999, 177- 184.

60. Zumriye A, Gultac B., Determination of the effective diffusion coefficient of phenol in calcium alginate immobilized Pseudomonas putida, Enzyme Microbial Technol., 25, 1999, 344-348.

61. Annadurai G, Balan MS, Murugesan T., Design of experiments in the biodegradation of phenol using immobilized Pseudomonas pictorium (NICM - 2077) on activated carbon. Bioproc. Eng. 22, 2000a. 101-107. 
62. Cho Y, Rhee S, Lee S., Influence of phenol on biodegradation of pnitrophenol by freely suspended and immobilized Nocardioides $\mathrm{sp}$. NSP.41, Biodegradation, 11, 2000, 21-28.

63. Garcia GI, Pena PRJ, Venceslada B, Martin AA, Santos MAM, Gomes ER., Removal of phenolic compounds from olive mill wastewater using Phanerochaete chrysosporium, Aspergillus terreus and Geotrichum candidum. Proc. Biochem., $85,2000,751-758$.

64. Loh KC, Tar PP., Effect of additional carbon sources on Biodegradation of phenol., Bull. Environ. Contam. Toxicol., 64, 2000, 756-763.

65. Nakamura Y, Sawada T., Biodegradation of phenol in presence of heavy metals, J. Chem. Technol. Biotechnol., 75, 2000, 137-142.

66. Baek S, Yin C, Lee S.,. Aerobic nitrate respiration by a newly isolated phenol degrading bacterium Alcaligenes P5.,Biotechnol. Lett., 23, 2001, 627- 630 .

67. Gonzalez G, Herrera G, Ma T, Garcia PM., Biodegradation of phenolic industrial wastewater in fluidized bed reactor with immobilized cells of Pseudomonas putida, Biores. Technol., 80, 2001, 137-142.

68. Loh KC, Liu J., External loop inversed fluidized bed aircraft bioreactor (EIFBAB) for treating high strength phenolic waste water, Chem. Eng. Sci., 56, 2001, 6171-6176.

69. Petruschka L, Burchardf G, Muller C, Weihe. C and Herrmann. H., The cyo operon of Pseudomonas putida is involved in carbon catabolite repression of phenol degradation. Mole. Genet. Genom., 266, 2001, 199-206.

70. Hao OJ, Kim MH, Seagren EA, Kim H., Kinetics of phenol and chlorophenol utilization by Acinetobacter sp., Chemosphere, 46, 2002, 797-807.

71. Prieto MB, Hidalgo A, Rodriguez FC, Serra JL, Llama MJ, Biodegradation of phenol in synthetic and industrial wastewater by Rhodococcus erythropitics. UPV-1 immobilized in air-stirred reactor with clarifier. Appl. Microbiol. Biotechnol. $58,2002,583-859$.

72. Godjevergova $\mathrm{T}$, Ivanova $\mathrm{D}$, Alexieva $\mathrm{L}$, Dimova D., Biodegradation of toxic organic components from industrial phenol production waste waters by free and immobilized Trichosporon cutaneum 57, Proc. Biochem., 38, 2003, 915920.

73. Quan X, Shi H, Wang J, Qian Y., Biodegradation of 2,4 dichlorophenol in sequencing batch reactors augmented with immobilized mixed culture, Chemosphere, 50, 2003, 1069-1074
74. Farighian A, Hill G, Headlen J, Pedias S., Enhancement of 4- Chlorophenol biodegradation using glucose, Clean Technol. Environ. Policy, 2003, 51-65.

75. Atagana HI., Biodegradation of phenol, ocresol and p-cresol by indigenous soil fungi in soil contaminated with creosote, World J. Microbiol. Biotechnol., 20, 2004, 851-858.

76. Hamed TA Emine B, Ulku M, Tanju M., The biodegradation of benzene, toluene and phenol in a two-phase system, Biochem. Eng., 32, 2004, 68-79.

77. Nair IC, Shashidhar S., Microbial degradation of phenol by a species of Alcaligenes isolated from a tropical soil, Soil sci., T.5, 3-(4), 2004, 47- 51.

78. Santos VL, Linardi VR., Biodegradation of phenol by a filamentous fungi isolated from industrial effluents-identification and degradation potential, Proc. Biochem., 39, 2004, 1001-1006.

79. Bielefeldt AR, Cort T., Dual substrate biodegradation of non-ionic surfactant and pentachlorophenol by Sphingomonas chlorophenolica RA2, Biotechnol. Bioeng, 89(6), 2005., 680-689.

80. Kargi F, Eker S., Removal of 2,4 dichlorophenol and toxicity from synthetic wastewater in a rotating perforated tube film reactor, Proc. Biochem., 40, 2005, 205-211.

81. Prpich GP, Daugulis AJ., Enhanced biodegradation of phenol by a microbial consortium in a solid- liquid two-phase partitioning bioreactor, Biodegradation, 16, 2005, 329-339

82. Arutchelvan V, Kanakasabai V, Elagovan R, Nagarajan S, Muralikrishna V., Kinetics of high strength phenol degradation using Bacillus brevis, J. hazardous Mat., 129,1, 3, 2006, 216-222.

83. Moeder M, Martin C, Schlosser D, Harynad J, Gorreeki T., Separation of technical 4nonylphenols and their biodegradation products by comprehensive two dimensional gas chromatography coupled to time of flame mass spectrometry. J. Chromatograph., A, 1107, 1(2), 2006, 223-239.

84. Stoilova I., Krastanov A., Stanchev V., Daniel D., Gerginova M., Alexieva Z., Biodegradation of high amounts of phenol, catechol, 2,4-dichlorophenol and 2,6-dimethoxyphenol by Aspergillus awamori cells, Enzyme and Microbial Technology, 39, 2006, 1036-1041.

85. Belouhova M., Yotinov I., Topalova Y.,Adaptive mechanisms of the biofilm communities in technologies with gradually and shock concentration increase of xenobiotic pollutants - 
functional and fish analysis, Ecological Engineering and Environment Protection, IX, 2017, 76-86.

86. Topalova Y., Dimkov R., Todorova Y., Daskalova E., Petrov P., Biodegradation of phenol by immobilized in peo-cryogel Bacillus laterosporus $b t-271$ in sequencing batch biofilter, Biotechnology \& Biotechnological Equipment, 25, 4, 2011, 26132619.

87. Satchanska G., Topalova Y., Dimkov R., Petrov P., Tsvetanov C., Selenska-Pobell S., Gorbovskaya A., Bogdanov V., Golovinsky E., Phenol biodegradation by two xenobiotics-tolerant bacteria immobilized in polyethylene oxide cryogels, Comptes rendus de l'Academie bulgare des Sciences, 62, 8, 2009, 957-964.

88. Satchanska G., Topalova Y., Dimkov R., Groudeva V., Petrov P., Tsvetanov C., SelenskaPobell S., Golovinsky E. Phenol degradation by environmental bacteria entrapped in cryogels, Biotechnology \& Biotechnological Equipment, 29, 3, 2015, 514-521.

89. Hristov A., Dilnora Gouliamova D., Lilyana Nacheva L., Kolishka Tsekova K., Biodegradation of phenol in the presence of heavy metals by free and immobilized cells of yeast association, Comptes rendus de l'Academie bulgare des Sciences, 65, 3, 2012, 335-340.

90. Kües, U., Fungal enzymes for environmental management, Curr. Opin. Biotech., 33, 2015 268-278.

91. Zhang, Y., Zeng, Z., Zeng, G., Liu, X., Liu, Z., Chen, M., Liu, L., Li, J., Xie, G.,. Effect of Triton X-100 on the removal of aqueous phenol by laccase analyzed with a combined approach of experiments and molecular docking. Colloids Surfaces Biointerfaces 97, 2012b, 7-12.

92. Prieto MB, Hidalgo A, RodriguezFernandez C, Serra JL, LlamaMJ., Biodegradation of phenol in synthetic and industrial wastewater by Rhodococcus erythropolis UPV-1 immobilized in an air-stirred reactorwith clarifier, Appl. Microbiol. Biotechnol., 58, 2002, 853-900.

93. Warhurst AM, Fewson CA., Biotransformations catalyzed by the genus Rhodococcus, Crit Rev Biotechnol.,14, 1994, 29-73.

94. Finnerty WR., The biology and genetics of the genus Rhodococcus, Annu. Rev. Microbiol., 46, 1992, 193-218.

95. Bell KS, Philp JC, Aw DWJ, Christofi N., The genus Rhodococcus, J. Appl .Microbiol.;85, 1998, 195-210.

96. van der Geize R, Dijkhuizen L. Harnessing the catabolic diversity of rhodococci for environmental and biotechnological applications, Curr. Opin. Microbiol. 7, 2004, 255-261.

97. Larkin MJ, Kulakov LA, Allen CC., Biodegradation and Rhodococcus - masters of catabolic versatility, Curr. Opin. Biotechnol., 16, 2005, 282-290.

98. Čejková A, Masák J, Jirků V, Veselý M, Pátek M, Nešvera J., Potential of Rhodococcus erythropolis as a bioremediation organism, World J. Microbiol. Biotechnol. 21, 2005, 317-321.

99. Annadurai G, Rajesh Babu S, Mahesh KPO, Murugesan T., Absorption and biodegradation of phenol by Chitosan immobilized Pseudomonas putida (Mcm.2174). Bioproc. Eng. 22: 2000b, 493501.

100. Godjevargova T, Alexieva Z, Ivanova D., Cell immobilization of Trichosporon cutaneum strain with phenol degradation ability on new modified polymer carries. Proc. Biochem. , 35, 2000, 699-704.

101. Topalova Y., Dimkov R., Merdjanov D., Two steps for speeding up of phenol detoxification, Biotechnology \& Biotechnological Equipment, 9:1, (1995) 55-59.

102. Gomes F., Ramos I., Wendt C., GirardDias W., De Souza W., Machado E., Miranda E., New insights into the in situ microscopic visualization and quantification of inorganic polyphosphate stores by 4',6-diamidino-2phenylindole (DAPI)-staining, Eur. J. Histochem., 57, 2013, 34.

103. Bitton G., Wastewater Microbiology, Wiley-Blackwell, Hoboken, 2011, 804.

104. Nguyen H., Le V, Hansen A., Nielsen J, Nielsen P., High diversity and abundance of putative polyphosphate accumulating Tetrasphaera-related bacteria in activated sludge systems, FEMS Microbiol. Ecol., 76, 2011, 256-267.

105. Yotinov I., Todorova Y., Schneider I., Daskalova E., Topalova Y., Comparison of the influence of nanodiamonds and single-walled nanotubes on phenol biodetoxification by Pseudomonas sp., Journal of Nanoscience and Nanotechnology, 17, 2017, 1031-1040.

106. Lengauer, T., Rarey, M.,.Computational methods for biomolecular docking, Curr. Opin. Struct. Biol. 6, 1996, 402.

107. Liu Z., Liu Y.,Zeng G.,Shao B., Chen M.,Li Z., Jiang Y., Liu Y., Zhang Y., Zhong H., Application of molecular docking for the degradation of organic pollutants in the environmental remediation:A review, Chemosphere, 203, 2018, 139-150. 


\title{
КЛАСИЧЕСКИ И НОВИ АСПЕКТИ В РАЗГРАЖДАНЕТО НА АРОМАТНИ КСЕНОБИОТИЩИ
}

\author{
Евгения К. Василева, Цветомила И. Пьрванова - Манчева, Венко Н. Бешков
}

\begin{abstract}
Резюме: Органичните химични съединения са широко разпространени в отпадъчните води от промишлеността, минералните извори, както и в замърсените подпочвени води. Фенолите се срещат в петролните рафинерии и химическите заводи, при производството на взривни вещества, смоли и кокс, при преработката на въглища, пестициди и текстилна индустрия. Основните замърсители в отпадъчните води на рафинериите включват феноли, полициклични ароматни въглеводороди, както и тежки метали. Сред тези токсични замърсители, фенолите са считани за най-опасни и са доста трудни за отстраняване. Тези съединения са токсични при относително ниски концентрации. Разграждането им се осъществява в резултат от метаболитната активност на голяма група микроорганизми като бактерии, гъби и дрожди. Съществуват съобщения за много микроорганизми, способни да разграждат фенол благодарение на активността на множество ензими. Тези ензими включват: оксигенази, хидроксилази, пероксидази, тирозинази и оксидази. Експерименти с подхранване са провеждани в различни биореактори за осъществяване на биоразграждането на фенола. При отстраняването на органични замърсители се използват чисти култури, но това може да доведе до създаването на токсични междинни съединения. Този проблем може да се преодолее при използването на консорциум от микроорганизми, които имат широк спектър от метаболитни свойства. В този обзор ние описваме също така и някои нови технологии за биоразграждане на фенол като: различни видове имобилизации, флуоресцентен in situ хибридизационен анализ, нанобиотехнологии и др.
\end{abstract}

Ключови думи: фенол, биоразграждане, микроорганизми, ензими, имобилизации, флуоресцентен in situ хибридизационен анализ, нанобиотехнологии

Institute of Chemical Engineering at

the Bulgarian Academy of Sciences

"Acad. G. Bonchev" str. Bl. 103

Sofia 1113, Bulgaria

Asst. Prof. Evgenia Krasimova Vasileva, PhD

Phone: 02-979-32-84

E-mail: jenivasileva96@gmail.com

Asst. Prof. Tsvetomila Ivanova

Parvanova-Mancheva, PhD

E-mail: mila_parvanova@abv.bg

Prof. Venko Nikolaev Beschkov, DSc

Phone: 02-870-20-88

E-mail: vbeschkov@yahoo.com

\author{
Институт по инженерна химия към \\ Българска Академия на Науките \\ ул. „Акад. Г. Бончев” бл. 103 \\ София 1113, България
}

Гл.ас.д-р Евгения Красимова Василева

Тел.: 02-979-32-84

E-mail: jenivasileva96@gmail.com

Гл.ас.Д-р Цветомила Иванова

Първанова-Манчева

E-mail: mila_parvanova@abv.bg

Проф. дтн Венко Николаев Бешков

Тел.: 02-870-20-88

E-mail: vbeschkov@yahoo.com 